\title{
POCHODZENIE ETNOLEKTU HAECNOWSKIEGO W ŚWIETLE FONETYKI I FONOLOGII HISTORYCZNEJ
}

\author{
MAREK DOLATOWSKI \\ Uniwersytet im. Adama Mickiewicza \\ dola_r@amu.edu.pl
}

\begin{abstract}
The origin of Halcnovian ethnolect in the light of historical phonetics and phonology The Halcnovian ethnolect is an old dialect of the Bielsko-Biała's language island, no more used in the everyday communication. There are few written documents which refer to his origin, so it is not known well. In this situation the linguistics, and especially the phonology, can help to find out the land of origin of the Halcnovian settlers. In this paper the author try to analyse the phonologic system of the ethnolect in comparison to the historic phonology of the German language that it derives from. The reference level is first of all the Middle High German (in addition, less taken into consideration, the Old High German and the Early New High German), because, how it results from the analysis, it was the last common stage of evolution. The outcome of the study doesn't contradict the information indicated in the few written documents - the ethnolect has probably emerged from the East Central dialects in the $14^{\text {th }}-15^{\text {th }}$ century.
\end{abstract}

Keywords: German dialectology, language island research, Halcnow, Halcnovian ethnolect, historical phonology, history of the German language

Schlüsselwörter: deutsche Dialektologie, Sprachinselforschung, Alzen, alznerischer Ethnolekt, historische Phonologie, deutsche Sprachgeschichte

Słowa kluczowe: dialektologia niemiecka, wyspa językowa, Hałcnów, etnolekt hałcnowski, fonologia historyczna, historia języka niemieckiego

Hałcnów to obecnie dzielnica Bielska-Białej, a do 1977 samodzielna wieś [por. Z dziejów...]; do dziś można łatwo zauważyć jego wiejski typ zabudowy. Podobnie jak reszta terenów wokół Bielska, trafił pod polskie panowanie po pierwszej 


\section{MAREK DOLATOWSKI}

wojnie światowej, charakteryzował się jednak dużym odsetkiem niemieckiej ludności, która liczebnościowo zresztą przeważała nad polską [por. Kuhn 1981: 376]. Po 1945 roku wysiedlono stąd Niemców i sprowadzono Polaków. Wieś stała się jednojęzyczna, po raz pierwszy w dokładnie zbadanym okresie dziejów - do drugiej wojny światowej wspólistniały tam trzy języki, a sama wieś, a raczej cały okręg bielski, stanowiły niemiecką wyspę językową. Przeważający był niemiecki, ojczysty dla większości mieszkańców wsi, poza tym polscy mieszkańcy używali polskiego (według spisu ludności z roku 1900 na ok. 2600 hałcnowian ok. 2000 podało niemiecki jako język ojczysty, a ok. 600 - polski [por. GRVKL]). Trzecim językiem był hałcnowski, miejscowy etnolekt używany do codziennej komunikacji, pozornie niezachowany do dzisiejszych czasów. Jednak na miejscu można się przekonać, że jest tam jeszcze kilka osób, które go znają i pamiętają, ale go na co dzień nie używają. Są to prawdopodobnie ostatni jego użytkownicy w Polsce.

Mapa 1. Bielsko-bialska wyspa językowa w okresie międzywojennym [źródło: Kuhn 1981: 467].

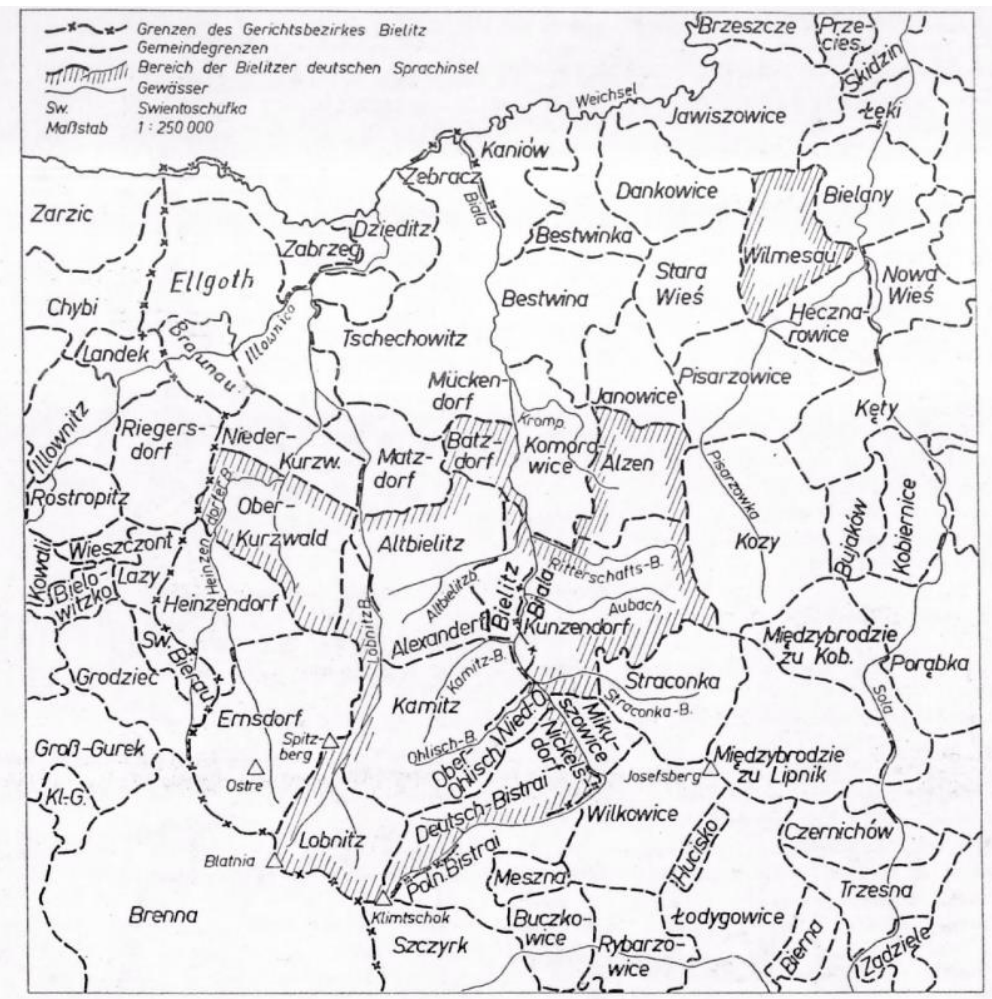

Karte 2: Raum der Bielitzer Sprachinsel, Gemarkungsgrenzen 
Dzięki zaangażowaniu Tymoteusza Króla z Wilamowic etnolekt został włączony przez Tomasza Wicherkiewicza z UAM do prowadzonego przez niego projektu „Dziedzictwo językowe Rzeczypospolitej. Baza dokumentacji języków zagrożonych", finansowanego przez Ministerstwo Nauki i Szkolnictwa Wyższego. W jego ramach analizowane i dokumentowane są wszystkie języki mniejszościowe używane $\mathrm{w}$ obecnej Polsce lub $\mathrm{w}$ jej granicach sprzed pierwszego rozbioru, przy głównym nacisku na łatgalski, polski jidysz, wilamowski i hałcnowski. Współwykonawcami projektu są językoznawcy i filologowie z UAM w Poznaniu1.

Etnolekt hałcnowski to najmniejszy z głównych języków projektu - w momencie pisania wniosku grantowego wiedziano o dwóch informatorkach. W miarę prac terenowych udało się znaleźć kolejnych rozmówców - na chwilę obecną jest ich ośmioro. Język ten nie wykształcił nigdy formy pisanej, nie był też obiektem dogłębnych analiz językoznawczych - m.in. dlatego praktycznie nie ma tekstów, nagrań i opracowań pochodzących spoza projektu. Udało się znaleźć jedynie jeden arkusz Wenkera, dwa powojenne nagrania na stronie Deutsches SprachArchiv [por. DSAr], tom pieśni i wierszy Karla Olmy, hałcnowianina przesiedlonego do Niemiec, pt. Alza. Wu de Putter wuor gesalza. Gedichte und Lieder einer untergehenden Mundart oraz powieść pt. Pflüger im Nebel tego samego autora, w której pojawiają się krótkie hałcnowskie wypowiedzi i zwroty. Ponadto od jednego z muzeów austriackich uzyskano ok. 20-stronicowy śpiewnik z pieśniami ludowymi z Hałcnowa, i istnieje prawdopodobieństwo, że w książce pt. Gedichte in der Mundart der deutschen schlesisch-galizischen Gränzbewohner, resp. von Bielitz-Biala Jakoba Bukowskiego z 1860 roku znajdują się dawne teksty hałcnowskie - ale ta książka jest dopiero konsultowana $\mathrm{z}$ informatorami.

Nagrania i materiały zebrane podczas badań projektowych stanowią wobec tych okoliczności podstawowy materiał do badań nad etnolektem. Tym ważniejsze jest zatem sprawne i efektywne zbieranie danych podczas wyjazdów. Jak dotąd, podczas ok. 15 wypraw badawczych, udało się zgromadzić ponad 40 godzin nagrań, z czego około połowa to nagrania w etnolekcie (reszta to m.in. polskie lub niemieckie opowieści o historii miejscowości, życiu przed wojną itp.). Zebrano bardzo różne typy tekstów: dialogi, opowiadania, monologi, czytanie tekstów pisanych, pieśni śpiewane (z notatek/śpiewników lub z pamięci), tłumaczenia zdań i słów. Dokumentacja nadal trwa i planowane są kolejne wyjazdy.

\footnotetext{
${ }^{1}$ Wyniki prac projektowych zostały opublikowane na początku roku 2014 (m.in. na stronie http://www.inne-jezyki.amu.edu.pl).
} 
Hałcnowski jest interesujący m.in. z tego punktu widzenia, że nie jest znana jego dokładna proweniencja. Początki wsi nie są dokładnie zbadane, zwłaszcza nie wiadomo, skąd przybyli niemieccy osadnicy, którzy założyli miejscowość. Wiadomo, że tereny te zostały spustoszone w wyniku najazdów tatarskich w XIII wieku, i że tutejsi władcy wezwali niemieckich osadników, by ponownie zaludnili te ziemie. Skąd dokładnie oni przybyli, nie jest pewne, ale podejrzewa się, że częściowo z Dolnego Śląska, dokąd mieli trafić z terenów dzisiejszych środkowych Niemiec w czasach Ostsiedlung (konkretnie w XIII wieku [por. Kronikarz 2012: 22n.; Kuhn 1981: 17nn.; Wicherkiewicz 1998: 15nn.]).

Badania historyczno-porównawcze w zakresie fonologii hałcnowskiej powinny pozwolić na dokładniejsze zlokalizowanie ojczyzny hałcnowskich kolonistów. Autor świadom jest jednak, że istnieje wiele czynników, które mogą uniemożliwić precyzyjne jej określenie - m.in. czas istnienia wyspy językowej, kontakty z handlowcami mówiącymi różnymi dialektami niemieckimi, kontakty z pobliskim (geograficznie) etnolektem wilamowskim, wpływy polskie, możliwość heterogenicznego (pod względem językowym) składu grupy osadniczej. Mimo to jednak podejmuje się takiej próby, za punkt wyjściowy uznając język starowysokoniemiecki, ponieważ już pierwszy rzut oka na hałcnowskie teksty wskazuje, że jest to etnolekt blisko spokrewniony z niemieckim.

Na początek należy zwrócić uwagę, że etnolekt nie wykształcił nigdy formy (tym bardziej normy) pisanej. Stosowana $w$ badaniach hałcnowska ortografia jest zatem prowizoryczna i może w trakcie dalszych badań ulec zmianie. Generalnie bazuje ona na zapisie fonologicznym języka niemieckiego, upraszczając jednak przede wszystkim notację samogłosek, do których stosuje się standardowe litery niemieckiego alfabetu; długość samogłoski oznacza następujące $h^{2}$, zrezygnowano z oznaczania napięcia, którego jeszcze dokładnie nie zanalizo-

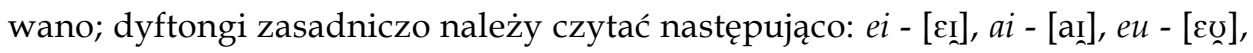
äu - [oy]. W przypadku spółgłosek uwzględnia się w zapisie ubezdźwięcznienie wygłosowe. Cytaty (np. z Olmy) przytaczane są w oryginalnej formie.

Poniżej przytoczony jest tekst bajki o wietrze północnym i słońcu, którą przetłumaczono z polskiego w trakcie badań, oraz jedna z pieśni ze zbioru Olmy. Po spisaniu nagrań pokazano zapis bajki informatorom i razem $\mathrm{z}$ nimi przeprowadzono $\mathrm{w}$ nim

2 Tylko w wypadku ortograficznego zapisu hałcnowskich słów. Dla dawnych głosek długich - ponieważ chodzi o transkrypcję fonologiczną - stosuje się standardową formę zapisu, tj. z dwukropkiem. 
zmiany według ich wskazówek. Tutaj prezentowany jest wynik tych działań bez żadnych późniejszych modyfikacji - obrazuje to, jak trudno jest hałcnowianom zapisać (konsekwentnie) ich własny język.

\section{TEKST 13:}

Der vynt fu nord schtryt sich myt dyr sun, var ej schterker/schtuorkyr. Doh kom(a) a vandyryr, dar vuor ümgekiezt üm/myt/in am vuoma mantl. Syh sent uf ains koma, [doh] dar (var) zvyngt a vandyryr a mantl äuszüzihen, [dar] vyt (an)erkant varda as/ols schtürker/schterker/schturker(er)/schtourkerer. Dyr nordvynt veht a suh

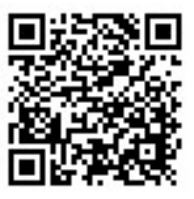
schtuo(r)k vi(h) [?] a(r) kunt. Je mehr ar hot gevyht doh hot sich dyr vandyryr beser ümgekiezt. Dyr vynt hot sich untergahn. Dyr sun hot schtourkyr geviemt, an sufü(r)t müst(a) dyr vandyryr de/a mantl äuszihn. A suh müst(a) dyr nordvynt zügahn do dy sun vuor schterker/schtuorkyr.

Wiatr północny i słońce kłócili się, kto jest silniejszy. Wtedy przechodził obok wędrowiec, otulony w ciepły płaszcz. Uzgodnili, że ten, kto szybciej zmusi wędrowca do ściągnięcia płaszcza, będzie uznany za silniejszego. Wiatr północny zawiał tak mocno, jak tylko mógł, jednak im mocniej wiał, tym cieplej wędrowiec opatulał się w płaszcz. Wiatr poddał się. Słońce zaświeciło mocniej, i wędrowiec od razu zdjął płaszcz. I tak wiatr musiał przyznać, że słońce jest silniejsze.

\section{TEKST 2:}

\section{Kjeta-Lied}

Wajd, Schtro(h)jwla, wajd, / wajd uf der Lajd! // Schtschona, dü O(h)s! / Fejndst ho(h)jt kaj Gros? / / Brehm summt an schtechjt ... / Kremm däj Gesechjt! // Räjß doch ne rem, / schmäjst mich sunst em! / / Senja echj wejl, / schprenja bäm Schpejl. / / Schtej, bräune Küh, / sej mer et zü! [...] [Olma 1988: 57]

\section{Pieśna pasterska}

Paś się, Schtro(h)jwla [imię krowy - przypis MD], paś się, / paś się na stoku! // Paś się, ty bydlaku! / Nie możesz znaleźć trawy? // Bąk brzęczy i żądli, / masuj (w swędzącym miejscu) swą twarz! // Nie wyrywaj się, / bo mnie przewrócisz! // Chcę śpiewać, / skakać, bawić się! / / Stój, brązowa krowo, / popatrz teraz na mnie! [...] [tłumaczenie własne - MD]

\footnotetext{
${ }^{3}$ Obok tekstu znajduje się kod QR, który, po zeskanowaniu za pomocą mobilnego urządzenia (np. smartfonu), umożliwia odtworzenie nagrania tego tekstu w wykonaniu hałcnowian. Obok przypisu podaję kod do jeszcze jednego nagrania innej pieśni Olmy, tym razem jednak nie odczytanej, a zaśpiewanej.
} 


\section{MAREK DOLATOWSKI}

Z samego słownictwa łatwo można wywnioskować, że jest to dialekt germański - świadczy o tym np. obecność przyimków fu 'z (pochodzenie), od', mit '(razem) $z$ ', äus 'z (pochodzenie, kierunek)', uf 'na', tsü 'do, w', zaimków ar 'on', zeh 'oni (pl.)', mer 'mnie (dat.)' czy rodzajnika nieokreślonego $a$. Dalsze precyzowanie będzie przebiegało tylko na podstawie danych fonologicznych.

O niemieckim charakterze etnolektu świadczy m.in. obecność starowysokoniemieckiej monoftongizacji. Gockim słowom ausō 'ucho', raups 'czerwony', maiza 'więcej' odpowiadają kolejno ö $(h) r$, roht, mehr, czyli formy bez dyftongu [por. Schmidt 2004: 201] ${ }^{4}$.

Dla dalszych ustaleń wykorzystana zostanie przede wszystkim lista Swadesha (czyli zbiór 207 wyrazów codziennego użytku, które tłumaczy się dla każdego nowo poznanego języka) w wersji hałcnowskiej [angielski oryginał zaczerpnięty z Vaux/Cooper 1999: 44nn.]. Już pierwsze spojrzenie na listę uświadamia, że jest to etnolekt, który doświadczył drugiej przesuwki spółgłoskowej, typowej dla dialektów środkowo- i górnoniemieckich. Można w niej znaleźć takie słowa jak: $e(i) c h$ 'ja', tsve 'dwa', tsohn 'ząb', voser 'woda', flus/flüs 'rzeka', fühs 'noga', vahs/vehs 'biały', asa 'jeść', beisa 'gryźć', tsü 'do', uf'na'; w innych nagraniach można znaleźć też następujące wyrazy: dörfa 'wsie (pl.)', pfah(r)t 'kon', schlihfa '(oni) spali', tsimer 'pokój', maXa 'robić'. Wszystkie te przykłady zawierają szczelinowe spółgłoski lub afrykaty tam, gdzie np. dialekty dolnoniemieckie i inne języki zachodniogermańskie zachowały spółgłoski wybuchowe (por. ang. two 'dwa', tooth 'ząb', water 'woda', foot 'noga', up 'na', make 'robić', hol. ik 'ja')5, wykazują zatem cechy typowe dla dialektów po drugiej przesuwce. Są jednak wyrazy, które zdają się przeczyć temu twierdzeniu: kohp(f)/kuop(f) 'głowa', p(f)lüXt 'obowiązek', a zwłaszcza opl 'jabłko'.

Ich obecność łatwo można wyjaśnić. Druga przesuwka nie była procesem jednolitym i chwilowym - nie dość, że trwała przez kilka stuleci, to jeszcze na różnych obszarach zaszła w różnym stopniu. Linie oddzielające dialekty po przesuwce i te

\footnotetext{
${ }^{4}$ Generalnie formy praindoeuropejskie lub pragermańskie potrzebne do porównań czerpane są ze słownika Proto-Indo-European Etymological Dictionary. A revised Edition of Julius Pokorny's "Indogermanisches Etymologisches Wörterbuch" [2007], słowników Gerharda Köblera Althochdeutsches Wörterbuch [1993] i Mittelhochdeutsches Wörterbuch [2007], słownika Herkunftswörterbuch Dudena [1989] oraz angielskiego słownika etymologicznego Online Etymology Dictionary [OED], rzadziej też ze słownika Dudena współczesnego języka niemieckiego [2006].

${ }^{5} \mathrm{~W}$ razie potrzeby podania form obcojęzycznych dla porównań autor korzystał przede wszystkim ze słowników internetowych: Wiktionary, Logos, PONS. Dotyczy to przede wszystkim języka holenderskiego.
} 
z głoskami niezmienionymi nie pokrywają się, każda para dźwięków charakteryzuje się inną izoglosą. Wobec tego można mówić o dialektach, które przeszły drugą przesuwkę w całości (górnoniemieckie), i o takich, które przeszły ją w mniejszym lub większym stopniu (środkowoniemieckie) [por. Schmidt 2004: 204nn.]. Sytuację tę ilustruje mapa nr 2:

\section{Mapa 2. Izoglosy przedstawiające zasięg poszczególnych zmian drugiej przesuwki kon- sonantycznej [źródło: Schmidt 2004: 78].}

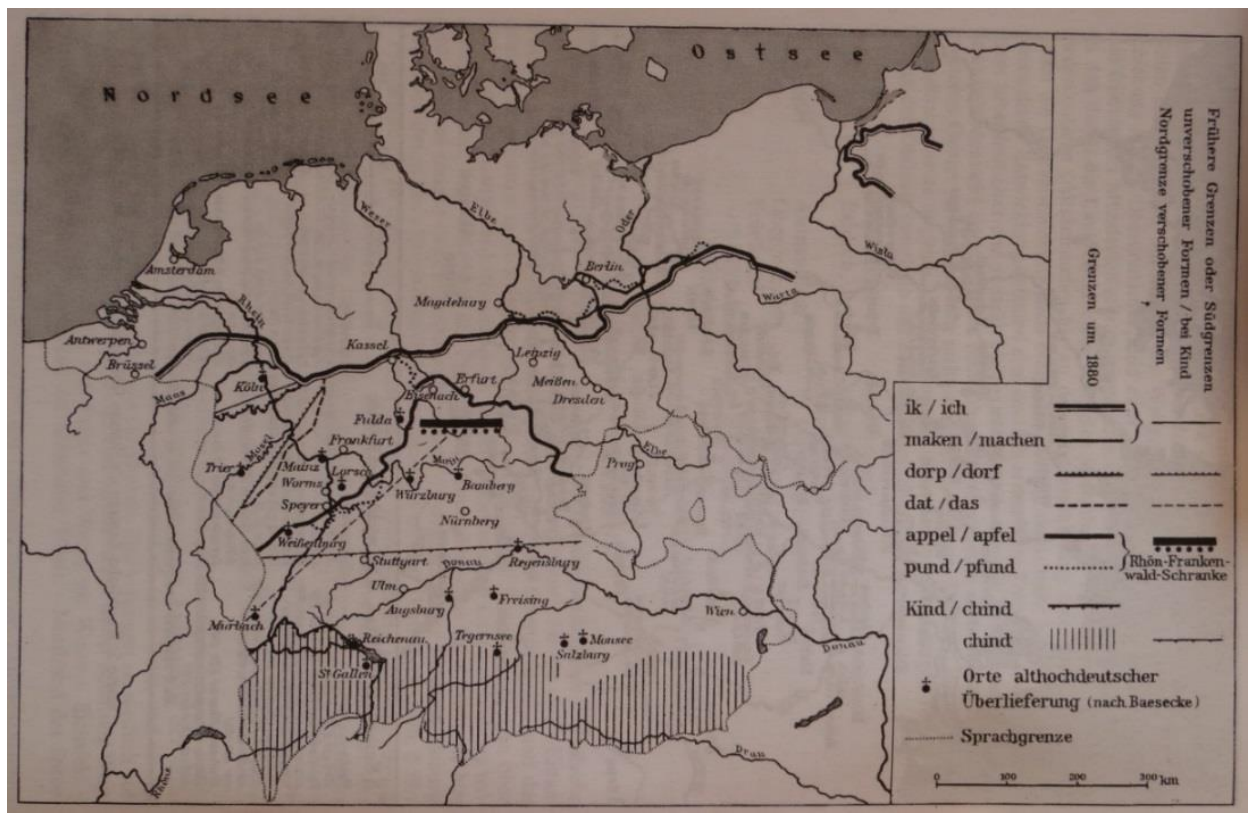

Fakt, że hałcnowski wykazuje formy przesunięte oraz nieprzesunięte, wyklucza zatem jego górnoniemieckie pochodzenie. Potwierdza to brak śladów przesunięcia $k>k c h$, znany z dialektów górnoniemieckich (por. hałcnowskie körn) [por. Schmidt 2004: 205].

Formy dörfa/dörfer 'wsie (pl.)' oraz hülfa '(oni) pomagali' wykazują przesunięte wygłosowe $f$ po $r$ i $l$. Proces ten nie zachodził generalnie w dialektach środkowofrankijskich [por. Schmidt 2004: 205], więc i tę grupę można wykluczyć.

Kolejne trzy słowa potwierdzają słuszność takiego wykluczenia: vohs 'co', dohs 'to', es 'ono' wykazują spółgłoski przesunięte, natomiast w dialektach środkowofrankijskich wygłosowe $t w$ tych wyrazach nie zostało przesunięte [por. Schmidt 2004: 205]. 


\section{MAREK DOLATOWSKI}

Następną uwzględnioną rozległą zmianą głosową jest rozwój pragermańskich spirantów $\hbar, g$ oraz $a$. W hałcnowskim, podobnie jak w większości niemieckich dialektów [por. Szulc 1991: 97n.], przeszły one zwykle w swe zwarte odpowiedniki: dźwięczne $b, g$ i bezdźwięczne $t$; przykłady gebörn 'urodzony (imiesłów przymiotnikowy bierny od rodziç)', be(i)nda 'wiązać', gahn 'dawać', flihga 'latać', blüt 'krew', tahk 'dzien', fo(h)ter 'ojciec'; można odnotować jednak także przykłady wykazujące inny rozwój, np. schtarva 'umierać', liev 'miły' (występuje u Olmy), forf 'kolor', päueri(s)ch (dosł. 'chłopski, wiejski'; nazwa etnolektu po hałcnowsku). W pierwszym przypadku (np. schtarva, liev) podobny rozwój zaszedł np. w dialektach dolnoniemieckich, w holenderskim (sterven, lief) i w angielskim (to starve, lief (przestarzałe)), jest też znany w dialektach środkowo- i reńskofrankijskich [por. Szulc 1991: 130n.], drugi łączy się z tendencją górnoniemiecką do przechodzenia głosek $\hbar, g$ do ich bezdźwięcznych zwartych odpowiedników [por. Szulc 1991: 97]. Słowa wykazujące taki rozwój są jednak rzadkie i można je uznać za być może - efekt zapożyczeń (choć np. wyraz schtarva nie należy do częstych zapożyczeń, jednak w tym przypadku, podobnie jak z forf, bezdźwięczna szczelinowa bywała jeszcze $w$ epoce środkowowysokoniemieckiej podobnie częsta jak dźwięczna zwarta [por. Schmidt 2004: 329; Szulc 1991: 144n.]; należy też zwrócić uwagę na to, że są to spółgłoski wygłosowe i podobnie w wygłosie zmieniła się głoska w wyrazie bohf'kobieta, żona', który prawdopodobnie jest zapożyczeniem z polskiego baba; możliwe zatem, że ten rozwój jest późniejszym nieregularnym procesem wtórnym). Nagłosowe $p \mathrm{w}$ miejscu $b$ natomiast było częste $\mathrm{w}$ niemieckich dialektach Czech jeszcze w epoce średniowysokoniemieckiej, zdarzało się też, pod wpływem południa, w dialektach wschodniośrodkowych, więc tu można doszukiwać się efektu kontaktów językowych [por. Schmidt 2004: 324].

Ogólnie można więc uznać, że rozwój pragermańskich dźwięcznych szczelinowych $\mathrm{w}$ hałcnowskim przypomina raczej stan $\mathrm{z}$ dialektów środkowoniemieckich niż ten górno- czy dolnoniemiecki. Jest to kolejna cecha ograniczająca językowe pochodzenie hałcnowian do środkowej części Niemiec.

W zakresie konsonantyzmu warto zwrócić uwagę też na fakt, że nagłosowe bezdźwięczne s zostało udźwięcznione przed samogłoską, a rozwinięte do $\int$ przed $t$ i $p$ por. schtain 'kamień', schtahp/schtäup 'kurz', schlank'wąż'. Nie obserwuje się zasadniczo analogicznego rozwoju w śródgłosie (który wykazują dialekty południowo-zachodnie); zanotowano natomiast słowo vürscht, z takim przejściem po $r$ [por. Schmidt 2004: 327n.]. Ogólnie więc sytuacja wygląda tak, jak w niemieckim standardowym. 
Istotne jest też wyodrębnienie się alofonu (potem fonemu) ç z X po samogłoskach przednich - dokonało się ono przede wszystkim w dialektach środkowoniemieckich, pozostając obce dialektom górnoniemieckim [Schmidt 2004: 328n.]. Hałcnowski wykazuje tę zmianę nieregularnie: obecna jest np. w słowach $e(i) c h$ 'ja', richtik 'prawidłowy' (obok riXtik), ra(h)cht 'prawy' (obok ra(h)Xts), nieobecna np. w teiX 'staw', diXt' 'gęsty', reiX 'kraj'.

Z przytoczonych danych konsonantycznych można wyciągnąć następujące wnioski: pierwsi hałcnowianie nie mówili dialektami dolnoniemieckimi, ponieważ w obecnym hałcnowskim obecna jest druga przesuwka; nie byli jednak z południa dzisiejszych Niemiec, gdyż jest ona obecna tylko częściowo; nie posługiwali się raczej dialektami środkowofrankijskimi ani wschodniofrankijskimi, można odrzucić również te reńskofrankijskie. Jedyna duża grupa dialektów, która pozostaje, to dialekty wschodniośrodkowoniemieckie.

Trudniejsze wydaje się ustalenie czasowego odłączenia się hałcnowskiego od niemieckiego kontinuum dialektalnego. W tym celu należy uwzględnić nie tylko zmiany konsonantyczne, ale też wokaliczne.

Sama druga przesuwka ogranicza potencjalny czas odłączenia się do maks. IX wieku. Na ten okres szacuje się zakończenie tego procesu [por. Schmidt 2004: 204]. Również fakt, że żadne zidentyfikowane zapożyczenie z polskiego nie wykazuje jego efektów, wskazuje na to, że kontakty polsko-hałcnowskie rozpoczęły się dopiero po IX wieku.

Od X wieku w niemieckich dialektach zaczęły być osłabiane samogłoski nieakcentowane - zaczęły one przechodzić w osłabione $e$ [ə] [por. Schmidt 2004: 202n.; Szulc 1991: 129]. Również w hałcnowskim osłabienie takie jest obecne (np. informatorzy próbując zapisać coś po hałcnowsku przeważnie zapisują samogłoski nieakcentowane jako $y$ ), jednak jest rzadsze niż w standardowym niemieckim. Przykładowo, bezokoliczniki kończą się zwykle na - $a$, nie na -en (w wymowie [ən]) - prawdopodobnie jest to pozostałość po pierwotnej końcówce -an czasowników starowysokoniemieckich [por. Szulc 1991: 108nn.], w której -a- zachowało swoją barwę, natomiast $-n$ zupełnie wypadło. Przez to w czasownikach można stwierdzić obecność dwóch samogłosek pełnych.

Od wieku XIII z południa zaczęła rozprzestrzeniać się tendencja do dyftongizacji długich samogłosek $i:, u:$ : $\ddot{u}$ :, docierając do dialektów wschodniośrodkowych w końcówce XIV wieku i dając w różnych obszarach różny efekt [por. Sulc 1991: 139n.]. Proces ten dotknął także analizowany etnolekt, z dość dużą regularnością - głoski te przeszły odpowiednio w ei, äu, äu. Przykłady: mei(n) 
'mój', veiter 'dalej', teiX 'staw', reiX 'kraj' (ale wa(h)s/we(h)s, obok weis, 'biały'); häut 'skóra', bäuX 'brzuch', läus 'pchła', häus 'dom'; fäuer 'ogien', näu 'nowy', schäune 'obora'. Interesujące jest zlanie się kontynuantów u: i ü:, do którego nie doszło w innych niemieckich dialektach; zresztą sam rozwój do takich dyftongów nie dokonał się nigdzie indziej.

Zaskakujące jest, że wśród przydomków hałcnowskich ${ }^{6}$ jest forma (według informatorów) zapożyczona z polskiego, która doświadczyła dyftongizacji: Pläuts, pochodzące od ptuca. Być może jednak przekonanie informatorów o polskim pochodzeniu słowa jest błędne - poza problemem z dyftongizacją brakuje wyraźnej motywacji do wykorzystania tego słowa jako przydomka. Możliwe jest zatem, że jest to kontynuant jakiegoś staroniemieckiego słowa.

Nieco inaczej sytuacja wygląda w przypadku dawnych dyftongów ie, uo, üe. Ich monoftongizacja rozpoczęła się na przełomie XI i XII wieku w środkowych Niemczech i stamtąd rozprzestrzeniał się na południe, dając ostatecznie np. w standardowym niemieckim odpowiednio $i$ : $u$ :, $\ddot{u}$ : [por. Schmidt 2004: 255, 311n.; Szulc 1991: 141]. W hałcnowskim znajdują się formy z monoftongiem (długim lub krótkim) i z dyftongiem, np. güht 'dobry', müter 'matka', vuor 'był (1., 3. os. 1. poj. cz. ter. t. ozn. str. czyn.)' , nie da się zatem ustalić jednoznacznie tendencji w tym zakresie.

Nieregularnie rozwinęły się też dyftongi ei, ou, öy. Przykładowo, pierwszy z nich przeszedł niekonsekwentnie w ai lub w $a(h)$ : ai 'jajko', schtain 'kamień', nain 'nie', ale też fla(h)sch 'mięso', braht (też breit) 'szeroki', klihn 'mały'. Drugi również wykazuje dwie możliwe kontynuacje, $a(h)$ i äu; przykłady: ahk 'oko', schtäup/schtahp 'kurz', ba(h)m/bäum 'drzewo'. Sytuacja jest zatem inna niż w standardowym niemieckim, jednak podobnie jak we wszystkich dialektach nie doszło generalnie do zlania kontynuantów dawnych długich monoftongów z kontynuantami wcześniej zanalizowanych dyftongów (pomijając niepewną sytuację z ou) [por. Szulc 1991: 139nn.]. Doszło natomiast do utożsamienia się kontynuantów różnych dawnych samogłosek długich (u: ü: do äu) lub, z mniejszą regularnością, dyftongów (ei, ou do $a(h))$.

W XIII wieku w dialektach środkowych zaszły dwa kolejne zjawiska wokaliczne, które można zaobserwować w hałcnowskim: krótkie samogłoski w sylabach otwartych wydłużyły swą artykulację, natomiast długie w sylabach zamkniętych zostały skrócone [por. Schmidt 2004: 312nn.]. Co ciekawe,

${ }^{6}$ Hałcnów był stosunkowo małą wsią, jednak często powtarzały się niektóre nazwiska (zwłaszcza Olma). Dla łatwiejszego rozpoznawania się nadawano wszystkim przydomki, i to ich używano na co dzień (do zaobserwowania także dziś). 
w przypadku wydłużenia zaobserwować można te same ograniczenia, które występowały w średniowysokoniemieckim: przed spółgłoskami $t$ i $m$ nie doszło do zmiany wymowy samogłoski, ale, w przeciwieństwie do standardu, także spółgłoski nie uległy wydłużeniu ${ }^{7}$. Stąd obecność w hałcnowskim np. słów hemelreiX 'królestwo niebieskie', imer 'zawsze' i sumer 'lato', z krótką pierwszą sylabą. $Z$ drugiej strony, podobnie jak w standardzie, wydłużone zostały nie tylko sylaby otwarte, np. lahver/lahber 'wątroba', ale też sylaby potencjalnie otwarte, np. w wyrazie tahk 'dzień'.

W późnej epoce średniowysokoniemieckiej w dialektach środkowoniemieckich obniżeniu uległy samogłoski wysokie $u$ i $\ddot{u}$ w otoczeniu spółgłoski nosowej [por. Szulc 1991: 143]. W hałcnowskim do obniżenia tego nie doszło - przykłady to sumer 'lato', sunst 'natomiast' (u Olmy), kund 'mógł (1., 3. os. 1. poj. cz. ter. t. ozn. str. czyn.)' (u Olmy; informatorzy podają formy z o: kont), zun 'słońce' (ale zontahk 'niedziela', obok zuntahk), geschtürva 'zmarły (imiesłów przymiotnikowy bierny od czasownika schtarva)', podwyższeniu uległ natomiast np. przyimek vun 'z, od' (u Olmy i z nagrań (fu)).

W dzisiejszym etnolekcie zaobserwować można zjawisko ubezdźwięcznienia obstruentów w wygłosie, które obecne jest i w polskim, i w niemieckim (od XI wieku [por. Schmidt 2004: 259; Szulc 1991: 131]). Nie można zatem jednoznacznie stwierdzić, czy cecha ta została w hałcnowskim odziedziczona, czy też zapożyczona z polskiego (zwłaszcza, że wszyscy obecni mówcy język ten znają bardzo dobrze). Hałcnowianie, którzy wyjechali do Niemiec (i zostali nagrani podczas badań do DSAr), znali dobrze niemiecki standardowy, więc również $\mathrm{w}$ ich wypadku możliwa jest interferencja, tym razem z niemieckiego; Olma stosuje ortografię wyraźnie opartą na niemieckiej i tego zjawiska nie zaznacza, więc nie można stwierdzić jej (nie)obecności w jego idiolekcie.

Wspomniane wcześniej zmiany z $s$, w hałcnowskim dość konsekwentne, datowane są na epokę średnio- i wczesnonowysokoniemiecką [por. Schmidt 2004: 327n.; Szulc 1991: 130n., 145].

Podobnie jak w niemieckim, dawnej zbitce $m b$ odpowiada dźwięk $m$, np. tsimer, üm. Proces ten zakończył się $\mathrm{w}$ epoce wczesnonowysokoniemieckiej, tj. po XV w., jednak jego początki sięgają epoki średniowysokoniemieckiej; wtedy przejście to pojawiło się $\mathrm{w}$ centralnych dialektach dzisiejszych Niemiec [por. Szulc 1991: 146].

7 W dzisiejszym standardzie niemieckim spółgłoski te znów są krótkie, poprzedzające je samogłoski również. 
Nie dokonało się w hałcnowskim zamykanie szczelinowego $v$ (do $b$ ) w wygłosie i po $l, r$, którego efekty można zauważyć w standardowym niemieckim. Było to zjawisko późnośredniowysokoniemieckie [por. Schmidt 2004: 329].

W XVI-XVII w. znane z dialektów południowych ubezdźwięcznianie nagłosowego $d$ przed $r$ pojawiało się często w dialektach środkowych [por. Schmidt 2004: 325]. Śladu tego zjawiska nie można jednak znaleźć w hałcnowskim (np. drüka 'przyciskać').

W epoce średniowysokoniemieckiej zaczął się proces epitezy $t$ w wygłosie, który dokonał się także $\mathrm{w}$ analizowanym etnolekcie, np.: uhbst 'owoce', mont/monda 'księżyc', jemant 'ktoś'. Zjawisko to trwało jeszcze w epoce wczesnonowysokoniemieckiej, rozprzestrzeniając się od centrum na południe [por. Schmidt 2004: 326n.].

Podsumowując należy najpierw stwierdzić, że dokładne określenie momentu oderwania się bielskiej wyspy językowej od kontinuum dialektalnego nie jest możliwe, m.in. z uwagi na fakt, że przez długi czas miała ona kontakty handlowe i polityczne z niemieckojęzycznymi miastami czy państwami, i na brak ogólnych (obejmujących całe lub większość terytorium) zmian po epoce wczesnonowysokoniemieckiej. Tutaj jednak zostaje podjęta próba lokalizacji czasowej rozerwania tej wspólnoty. Z powyższej analizy wynika, że etnolekt hałcnowski dzieli z wieloma dialektami niemieckimi większość zmian średniowysokoniemieckich, nie ma natomiast wielu zmian z epoki późniejszej. Każe to doszukiwać się momentu zerwania kontaktów w wieku XIV, ponieważ to jego połowę uznaje się za moment przejścia średniowysokoniemiecki --> wczesnonowysokoniemiecki. Dokładniej można nawet przypuszczać, że zerwanie kontaktów dokonało się w drugiej połowie stulecia (wskazuje na to obecność zjawisk datowanych na jego połowę - monoftongizacji, dyftongizacji, skrócenia i wzdłużenia). Ewentualnie możliwe jest też odłączenie się na początku XV wieku.

Nieliczne i krótkie są wzmianki o Hałcnowie z samych jego początków. Pierwsze źródło wspominające miejscowość pochodzi z 1. poł. XV w. W źródłach z XVIXVII w. hałcnowian często nazywano kolonistami, podkreślając tym ich późniejsze przybycie niż innych tutejszych osadników (osady typu Kozy, Lipnik, Pisarzowice, Komorowice pochodzą z pierwszej połowy XIV w.) [por. Kronikarz 2012: 22n.]. Zgadza się to z powyższymi ustaleniami chronologicznymi.

Terytorialne pochodzenie hałcnowskich osadników trudniej ustalić. Według źródeł i badaczy założyciele całej wyspy językowej pochodzili ze Śląska (dlatego jest ona sekundarną wyspą językową). Tam natomiast, jak się przypuszcza, trafili z Saksonii, Turyngii lub Hesji [por. Kuhn 1981: 17nn.; Wicherkiewicz 
1998: 15nn.]. Część tych terenów (zwłaszcza Dolny Śląsk) to miejsce występowania dialektów wschodniośrodkowoniemieckich [por. mapa 1], które, jak ustalono powyżej, mogą być rozpatrywane jako najbardziej prawdopodobne dialekty wyjściowe dla etnolektu.

Jak widać, dane, które uzyskano z analizy językoznawczej, nie stoją w sprzeczności ze skąpymi danymi źródłowymi, można nawet uznać, że je potwierdzają. Oczywiście autor jest świadom, że to analiza tylko części zebranego materiału. Uwzględnienie całości może przede wszystkim umożliwić doprecyzowanie obecnych wniosków. Także uwzględnienie większej ilości zmian głosowych z niemieckojęzycznego obszaru dawnych epok powinno pomóc w dokładniejszym ustaleniu pochodzenia etnolektu. Należy jednak pamiętać o kilku okolicznościach, które istotnie mogą utrudnić uzyskanie precyzyjnych wniosków. Po pierwsze, hałcnowski rozwijał się na styku kultury polskiej i niemieckiej, a burzliwa historia polityczna tego obszaru sprawiła, że miał on bliższy kontakt raz z językiem polskim, a raz z niemieckim. Obydwa mogły wywrzeć nań silny wpływ, i to nie tylko w sferze leksyki, ale też w wymowie; po wielu latach trudno będzie jednak odróżnić wewnętrzne tendencje rozwojowe od tych zapożyczonych. Po drugie, osadnicy prawdopodobnie pochodzili z Dolnego Śląska, ale tam mogli trafiać z różnych obszarów Niemiec. Jest prawdopodobne, że hałcnowski rozwinął się z jakiegoś dialektu mieszanego, wobec czego mogą w nim występować cechy typowe dla wariantów językowych różnych terenów. Przy dalszych badaniach trzeba będzie uwzględnić też taką ewentualność. Przydatnym może okazać się również uwzględnienie także innych podsystemów języka, tzn. morfoskładni i leksyki, zwłaszcza badania morfologiczne mogą dać ciekawe wyniki. Słownictwo jest zbiorem zbyt otwartym, by, jak się wydaje, jego analiza mogła dać wymierne korzyści dla tego typu badań - jednak naturalnie jest ona konieczna, by np. uwzględnić procentowy udział polskich zapożyczeń. Ponadto ciekawych wniosków może dostarczyć także zbadanie kultury hałcnowskiej. Wszystko to są kolejne zadania, które czekają autora oraz informatorów w ciągu najbliższych kilku lat. 


\section{MAREK DOLATOWSKI}

\section{Bibliografia}

BUKOWSKI J., 1860: Gedichte in der Mundart der deutschen schlesisch-galizischen Gränzbewohner, resp. von Bielitz-Biala, Bielitz: Verlag von Ludwig Zamarski.

DSAr: Deutsches SprachArchiv [on-line], [dostęp 26.06.2014]. Dostępny w: http://dsav-wiss.ids-mannheim.de.

DUDEN, 2006: Deutsches Universalwörterbuch [CD-ROM], Mannheim: Dudenverlag. DUDEN, 1989: Herkunftswörterbuch, Mannheim: Dudenverlag.

Dziedzictwo językowe Rzeczypospolitej. Baza dokumentacji zagrożonych języków [online], Wydział Neofilologii UAM, Poznań 2014 [dostęp 26.06.2014]. Dostępny w: http://www.inne-jezyki.amu.edu.pl.

GRVKL: Gemeindellexikon der im Reichsrate Vertretenen Konigreiche und Lander, herausg. von der K.K. Statistischen Zentralkommission, B. XII. Galizien, Wien 1907: K.K. Hof- und Staatsdruckerei, p. 19 [djvu], [dostęp 25.11.2012]. Dostępny w: http://wiki-commons.genealogy.net/images/5/54/Oesterreich-12.djvu?djvuopts\&page=19.

KÖBLER G., 2007, Mittelhochdeutsches Wörterbuch [on-line], [dostęp 26.06.2014]. Dostępny w: http:/ / www.koeblergerhard.de/germanistischewoerterbuecher/mittelhochdeutscheswoerterbuch/mhdwbhin.html.

KÖBLER G., 1993: Althochdeutsches Wörterbuch [on-line], [dostęp 24.06.2014]. Dostępny w: http://www.koeblergerhard.de/ahdwbhin.html.

KRONIKARZ (pseud.), 2012: Z dziejów Hałcnowa: Kiedy założono Hałcnów?, w: „W MOIM KOŚCIELE“, nr 94, 7/2012, s. 22-23.

KUHN W., 1981: Geschichte der deutschen Sprachinsel Bielitz (Schlesien), Würzburg: Holzner Verlag.

LOGOS: Logos Dictionary Volunteers [on-line], Logos Group, 2014 [dostęp 28.06.2014]. Dostępny w: http:/ / www.logos.it.

OED: Online Etymology Dictionary [on-line], 2001-2014 [dostęp 27.06.2014]. Dostępny w: http://www.etymonline.com.

OLMA K. (pseud. ZÖLLNER Michael), 1988: Alza. Wu de Putter wuor gesalza. Gedichte und Lieder einer untergehenden Mundart, Dülmen: Oberschlesischer Heimatverlag.

OlMA K. (pseud. ZÖLlNER Michael), 1963: Pflüger im Nebel. Das Schicksal eines beskidenländischen Bauerngeschlechts. Roman aus den Jahren 1938 bis 1958, Augsburg: Oberschlesischer Heimatverlag. 
PIEED, 2007: Proto-Indo-European Etymological Dictionary. A revised Edition of Julius Pokorny's "Indogermanisches Etymologisches Wörterbuch" [pdf], DNGHU Adsoquiation - Indo-European Language Association, [dostęp 18.09.2010]. Dostępny w: http://dnghu.org/en/Indo-European etymological dictionary.

PONS: PONS Online-Wörterbuch [on-line], PONS GmbH, Stuttgart 2001-2014 [dostęp 22.06.2014]. Dostępny w: http://de.pons.com.

SCHMIDT W., 2004: Geschichte der deutschen Sprache, Stuttgart: S. Hirzel Verlag.

SzUlC A., 1991: Historia języka niemieckiego, Warszawa: Wydawnictwo Naukowe PWN.

VAUX B., COOPER J., 1999: Introduction to Linguistic Field Methods. MünchenNewcastle: LINCOM EUROPA.

Wiktionary [on-line], Wikimedia Project, [dostęp 26.06.2014]. Dostępny w: http://www.wiktionary.org.

Z DZIEjów: Z dziejów Hałcnowa, w: Halcnow.pl [on-line], [dostęp 12.06.2013]. Dostępny w: http://halcnow.pl/historia/historia-hacnowa/12-z-dziejow-hacnowa. 


\section{Der Ursprung des Alznerischen Ethnolekts im Lichte der historischen Phonetik und Phonologie (Zusammenfassung)}

Der Alznerische Ethnolekt ist einer der Dialekte der Bielitz-Bialaer Sprachinsel und wird im Alltag nicht mehr gesprochen. Es gibt wenige Dokumente, die die Anfänge der Sprachinsel beschreiben, deswegen sind sie größtenteils unklar. In solch einer Situation kann die Linguistik, besonders die historische Phonologie, bei der Suche nach der Urheimat der Alznerischen Kolonisten behilflich sein. Im Artikel versucht der Autor das phonologische System des Ethnolekts zu analysieren, indem er es mit den Systemen älterer Entwicklungsstufen der deutschen Sprache vergleicht. Die Vergleichsbasis ist dabei das Mittelhochdeutsche (neben den seltener berücksichtigten Althochdeutsch und Frühneuhochdeutsch), weil es, der Forschung nach, die letzte gemeinsame Entwicklungsstufe war. Die Ergebnisse der Analyse widersprechen nicht den Angaben, die in den wenigen Dokumenten zu finden sind - wahrscheinlich hat sich der Ethnolekt im 14.-15. Jahrhundert von den ostmitteldeutschen Dialekten abgetrennt.

\section{UARODOWY PROGRAM \\ 1. ROZWOJU HUMANISTYKI}

Praca naukowa finansowana w ramach programu Ministra Nauki i Szkolnictwa Wyższego pod nazwą „Narodowy Program Rozwoju Humanistyki” w latach 2012-2013. 